DOI: $10.19195 / 0137-1134.119 .20$

\author{
ANNA MŁYNARSKA-SOBACZEWSKA \\ ORCID: 0000-0003-3029-2836 \\ Instytut Nauk Prawnych PAN
}

\title{
RADA SĄDOWNICTWA SZKOCJI I SZKOCKA RADA NOMINACJI SĘDZIOWSKICH
}

\begin{abstract}
Abstrakt: Artykuł przedstawia strukturę, kompetencje i funkcje dwóch ciał odpowiedzialnych w Szkocji za ochronę niezależności sądownictwa. W tekście zaprezentowano także reformy, jakim podlega szkockie sądownictwo w XXI wieku, oraz strukturę sądownictwa w Szkocji.
\end{abstract}

Słowa kluczowe: sądownictwo szkockie, nominacje sędziowskie w Szkocji, niezależność sądownictwa w Szkocji

Sądownictwo Wielkiej Brytanii w ostatnich dwóch dekadach podlega poważnym zmianom, także w zakresie pozycji ustrojowej, zwłaszcza w zakresie dokładniejszego niż dotychczas uregulowania relacji między sądownictwem a pozostałymi podmiotami władzy w państwie. W Anglii i Walii konstytucjonalizacja tej relacji znalazła wyraz w tak zwanym konkordacie, określającym relacje między Lordem Kanclerzem (Lord Chancellor) a przewodniczącym sądów Anglii i Walii (Lord Chief of Justice), znacznie zmniejszając kompetencje Lorda Kanclerza w odniesieniu do sprawowania wymiaru sprawiedliwości; zmiany te zostały następnie uregulowane w Constitutional Reform Act z 2005 roku, który stał się — oprócz przyjęcia Human Rights Act i Devolutionary Acts z 1998 roku ${ }^{1}$ - jednym z kamieni węgielnych nowego ustroju konstytucyjnego na $\mathrm{Wyspach}^{2}$. Szkocka ustawa o władzy sądowniczej i sądach (The Judiciary and Courts Act) z 2008 roku $^{3}$ jest

1 Jednym z efektów Devolutionary Acts, a dokładnie Scotland Act, było powstanie, a dokładniej — wskrzeszenie szkockiego parlamentu, którego działalność zakończył Akt o Unii w 1707 roku; zob. szerzej D. Sharp, Parliamentary Sovereignty: A Scottish Perspective, „Cambridge Student Law Review" 6, 2010, s. 135.

2 E.F. Delaney, Judiciary Rising: Constitutional Change in the United Kingdom, „Northwestern University Law Review" 108, 2014, nr 2, s. 545-547 i cyt. tam literatura.

3 Ustawa uchwalona przez parlament szkocki 25 września 2008 roku, Royal Assent otrzymała 29 października 2008 roku. 
wyrazem podobnej tendencji, czyli próby ustawowego uregulowania relacji między władzą sądowniczą a wykonawczą ${ }^{4}$, choć, jak zauważają szkoccy autorzy, zmiany te mają nieco odmienny charakter z powodu odrębności w dotychczas funkcjonującym modelu sądownictwa w Szkocji i pozycji szkockiego Lorda Kanclerza ${ }^{5}$. Akt ten wprowadził ustawowe gwarancje niezawisłości sędziowskiej, dokładnie uregulował sposób powoływania sędziów, a także zwiększył transparentność i rozliczalność władzy sędziowskiej między innymi poprzez zmiany w regulacji procedur odpowiedzialności dyscyplinarnej ${ }^{6}$. Ustawa o władzy sądowniczej i sądach jest najważniejszym efektem reformy w zakresie sądownictwa i fundamentalnym aktem gwarantującym niezależność szkockiej judykatury?

\section{STRUKTURA SĄDOWNICTWA}

Sądownictwo Szkocji ma niezwykle złożoną strukturę i wielowiekową historię $^{8}$. Najwyższym sądem cywilnym jest Court of Session, który składa się z izby wewnętrznej (Inner House), pełniącej funkcję sądu apelacyjnego, z kolei od orzeczeń tej izby strony mogą odwołać się do Sądu Najwyższego Zjednoczonego Królestwa. Izba zewnętrzna (Outer House) jest natomiast sądem pierwszej instancji. Z kolei w sprawach karnych najwyższym sądem jest High Court of Justiciary, pełniący funkcję sądu I instancji w sprawach najcięższych przestępstw (poprzez oddziały w większych miastach Szkocji oraz w Edynbugu) oraz sądu apelacyjnego 9 .

Szkocja podzielona jest na sześć okręgów sądowych (sheriffdom); w każdym okręgu działa jeden główny sędzia (Sheriff Principal), który rozpoznaje odwołania w sprawach cywilnych, a ponadto jest odpowiedzialny za zarządzanie sheriff courts w swoim okręgu. Sprawy w sądach tej kategorii rozpoznawane są przez sędziów tytułowanych szeryfami (Sheriff), sądy te orzekają w sprawach cywilnych, spadkowych i karnych; karne Sheriff Appeal Courts, powstałe w 2015 roku, orzekają także jako sądy odwoławcze od orzeczeń Sheriffs i sądów sędziów pokoju (Justice of Peace Courts) — sądów właściwych w drobniejszych sprawach kar-

4 J. Harrison, Judging the Judges: The New Scheme of Judicial Conduct and Discipline in Scotland, „Edinburgh Law Review” 13, 2009, nr 3, s. 427-428.

5 J. McCluskey, Unnecessary and Misconceived: Some Reflections on the Judiciary and Courts (Scotland) Bill, ,Edinburgh Law Review” 12, 2008, nr 2, s. 289-290.

6 Ibidem, s. 428.

${ }^{7}$ O znaczeniu tego aktu zob. G.F.M. Little, The Reform of the Scottish Judiciary, [w:] Law-Making and the Scottish Parliament, red. E.E. Sutherland, Edinbourgh 2014, s. 183.

8 Warto nadmienić, że — jak wskazują niektórzy autorzy — właśnie na hierarchicznej strukturze sądów szkockich oraz ich relacji z parlamentem wzorowana jest regulacja art. III Konstytucji USA. J.E. Pfander, D.D. Birk, Article III and the Scottish Judiciary, „Harvard Law Review” 124, 2011, nr 7, s. 1615-1620.

9 https://www.encj.eu/images/stories/pdf/workinggroups/Timeliness/response_questionnaire_timeliness_scotland.pdf (dostęp: 27.11.2019). 
nych ${ }^{10}$, w sądach tych orzekają sędziowie pokoju, czyli sędziowie niezawodowi i nieposiadający wykształcenia prawniczego, działając w asyście sekretarza (clerk), będącego wykształconym prawnikiem.

Oprócz tego w Szkocji działają dwa sądy o szczególnej właściwości:

— The Court of the Lord Lyon - właściwy w sprawach heraldycznych,

— The Scottish Land Court — rozstrzygający spory między właścicielami ziemskimi i dzierżawcami ${ }^{11}$.

Trzeba także wspomnieć, że w Szkocji funkcjonuje odrębny organ, Kolegium Sprawiedliwości (The College of Justice), złożony z sądów najwyższych (to jest Court of Session, the High Court of Justiciary), a także urzędu sądowego księgowego, czyli instytucji odpowiedzialnej za finanse sądów (the Office of the Accountant of Court) i audytora Sądu Najwyższego (Auditor of the Court of Session). Kolegium przewodniczy Lord President, sędziowie zaś sądów wchodzących w skład Kolegium mają tytuły senatorów Kolegium Sprawiedliwości ${ }^{12}$.

Wszystkie sądy zarządzane są przez Scottish Courts and Tribunals Service (SCTS dawniej: Scottish Courts Service — Szkocką Służbę Sądową). Jest to niezależna organizacja, utworzona ustawą o sądownictwie i sądach z 2008 roku $^{13}$, która ma zapewniać administracyjne wsparcie i obsługę wszystkim sądom szkockim. Ciału temu przewodniczy Lord President, Przewodniczący Court of Session, czyli sędzia znajdujący się na szczycie hierarchii władzy sądowniczej.

\section{RADA SĄDOWNICZA SZKOCJI - POWOŁANIE I KOMPETENCJE}

W styczniu 2007 roku Lord President utworzył Radę Sądowniczą Szkocji (Judicial Council for Scotland), która działa na podstawie swojego statutu i jest zgodnie $z$ nim $^{14}$ ciałem doradczym Przewodniczącego Sądu Najwyższego (the Lord President of the Court of Session) oraz całego stanu sędziowskiego w sprawach dotyczących wymiaru sprawiedliwości. Zadania Rady są sformułowane w art. 2 statutu i dotyczą ochrony niezależności sądownictwa, należnej wymiarowi sprawiedliwości, ochrony i zapewnienia prawidłowego funkcjonowania wymiaru sprawiedliwości. Rada ma także stanowić forum wymiany i koordynacji

$10 \mathrm{https} / /$ e-justice.europa.eu/content_ordinary_courts-18-SC-pl.do?clang=en (dostęp: 17.09.2018).

11 http://www.scotland-judiciary.org.uk/16/0/Court-Structure (dostęp: 17.09.2018).

12 Z Kolegium związane są także inne ciała zrzeszające prawników najwyższej rangi, występujących przed sądami najwyższymi, takie jak: Faculty of Advocates, the Society of Writers to Her Majesty's Signet and the Society of Solicitors in the Supreme Courts of Scotland, https://web.archive.org/web/20070704181531/http://www.scotcourts.gov.uk/docs/you_and_us/recruitment/SCS\%20 An\%20Introduction.pdf (dostęp: 19.09.2018).

13 The Judiciary and Courts (Scotland) Act 2008.

${ }^{14}$ Constitution of the Judicial Council for Scotland General. 
poglądów i działań sędziów zmierzających do tych celów, ponadto ma troszczyć się o interesy władzy sądowniczej. Kolejnym zadaniem Rady jest udzielanie wskazówek i ujednolicanie praktyki w zakresie kwestii etycznych oraz innych zagadnień związanych z funkcjonowaniem wymiaru sprawiedliwości ${ }^{15}$. Rada jest ciałem opiniodawczo-konsultacyjnym przy Przewodniczącym Sądu Najwyższego (Lord President of the Court of Session).

Rada Sądownictwa Szkocji w swoim statucie wyraźnie zastrzega, że nie ma kompetencji ciał reprezentujących poszczególne kategorie sędziów, takich jak Rada Sędziów Sądu Najwyższego (Judges' Council of Court of Session), stowarzyszenie sędziów okręgowych (szeryfów - Sheriffs' Association) czy niepełnoetatowych szeryfów (Part-time Sheriffs' Association) oraz stowarzyszenie sędziów pokoju (Scottish Justices Association). Należy też podkreślić, że Rada Sądownictwa Szkocji nie jest właściwa w kwestiach związanych z procesem powoływania sędziów szkockich — te kompetencje ma inny organ, to jest Rada Nominacji Sędziowskich (The Judicial Appointments Board).

\section{SKŁAD RADY SĄDOWNICTWA SZKOCJI}

Członkowie Rady Sądownictwa Szkocji dzielą się na dwie kategorie: pierwsza z nich to wiryliści ${ }^{16}$, do których należą: Session),

- Przewodniczący Sądu Najwyższego (the Lord President of the Court of

— the Lord Justice Clerk ${ }^{17}$, czyli druga osoba w szkockim świecie sędziowskim; to sędzia, który jest Przewodniczącym drugiego wydziału wewnętrznej izby

15 Przedmiot działania Rady został sformułowany w Statucie następująco:

„2. The objectives of the Council are:

(a) to preserve the independence of the judiciary;

(b) to protect and promote the due administration of justice;

(c) to co-ordinate the views and actions of the judges to those ends;

(d) to promote the professional and pastoral interests of the judiciary;

(e) to provide guidance to the judiciary on questions of ethics, and other matters of relevance to the due administration of justice;

(f) to facilitate communication between the various branches of the judiciary and, where appropriate, collect and collate their views;

(g) to provide information and advice to the Lord President so that he may be aware of the views of the judiciary; and

(h) to deal with all matters of concern to the judiciary".

16 Warto dodać, że stan sędziowski jest w Szkocji ukształtowany pod wpływem wielowiekowej tradycji, na przykład urząd Lord of Justice Clerk wywodzi się z czasów siedemnastowiecznej Privy Council of Scotland, osoba piastująca go stała się następnie przewodniczącym reformowanego wówczas sądu karnego (High Court of Justiciary).

17 Lord Justice Clerk (funkcję tę sprawuje od 2016 lady Dorrien) jest także, oprócz Lorda Kanclerza, jednym z kilkorga najwyższych urzędników w państwie z kręgu High Officers of the 
w Sądzie Najwyższym (President of the Second Division of the Inner House of the Court of Session), sprawuje także funkcję zastępcy Przewodniczącego Sądu Najwyższego,

— sędzia senior spośród szkockich sędziów zasiadających w Sądzie Najwyższym Zjednoczonego Królestwa,

- przewodniczący Sądu Ziemskiego (the Scottish Land Court).

Do drugiej kategorii należą sędziowie wybierani w odpowiednich grupach:

— po dwóch sędziów Izby Wewnętrznej i Zewnętrznej Sądu Najwyższego, wybranych przez sędziów tego sądu,

— jeden z sędziów wybranych przez sędziów kierujących sądami w okręgu (głównych szeryfów),

— dwóch sędziów z sądów działających w okręgach (szeryfów) wybranych przez Związek Sędziów Szeryfów (Sheriffs' Association),

- sędzia niepełnoetatowy, wyznaczony przez swój związek sędziów (Part-Time Sheriffs' Association);

- dwóch przedstawicieli stanu sędziowskiego orzekających w trybunałach, wybranych przez Szkockie Forum Trybunałów (Scottish Tribunals Forum) oraz

— dwóch sędziów pokoju, wybranych przez Szkockie Stowarzyszenie Sędziów (Scottish Justices' Association).

Dodatkowych członków do pomocy w pracach Rady może wskazać Przewodniczący Sądu Najwyższego (Lord President of the Court of Session).

Członkowie wiryliści pełnią swoje funkcje w Radzie przez czas sprawowania swoich urzędów, natomiast czas trwania mandatu członków wybieranych jest wyznaczony przez odpowiednie gremia sędziowskie. Każdy z członków Rady może mianować osobę, która będzie go zastępować podczas posiedzeń Rady albo jej komitetów.

\section{TRYB DZIAŁANIA, ORGANIZACJA I PRAKTYKA}

Rada Sądownictwa Szkocji odbywa rocznie dwa posiedzenia plenarne — w sesji letniej i zimowej ${ }^{18}$, w praktyce posiedzenia te odbywają się w maju i w październiku. Ponadto posiedzenie może odbyć się, gdy „za radą Komitetu Wyko-

State. Szerzej o genezie i ewolucji pozycji oraz kompetencji najwyższych urzędników stanu w zakresie wymiaru sprawiedliwości i sądownictwa I. Field, Crime Fighters and Border Guards: The Scottish Law Officers in Comparative Perspective, „Bond Law Review” 23, 2012, nr 2, s. 28-30.

18 W Szkocji funkcjonuje pojęcie roku prawnego podzielonego na okresy, w których sądy odbywają swoje posiedzenia; współcześnie Kolegium Sprawiedliwości dokonuje podziału roku na trzy takie okresy, czyli sesje sądowe: zimową (od końca września do ostatniego piątku przed Bożym Narodzeniem), wiosenną (od początku stycznia do końca marca) i letnią (od końca kwietnia do początku lipca). 
nawczego Przewodniczący Sądu Najwyższego uzna to za stosowne"19. Komitet Wykonawczy Rady składa się z sędziego Izby Wewnętrznej i sędziego Izby Zewnętrznej Sądu Najwyższego (Court of Session), przy czym nie może to być Lord President ani Justice Clerk, jednego sędziego szeryfa głównego, jednego sędziego szeryfa, sędziego pokoju oraz jednego z członków trybunałów. Przewodniczący Sądu Najwyższego może powołać dodatkowych członków Komitetu Wykonawczego. Komitet Wykonawczy odbywa posiedzenia przed każdym posiedzeniem Rady, przygotowując sprawy, które mają być przedmiotem obrad oraz wówczas, gdy uzna to za konieczne. W celu opracowania poszczególnych spraw będących w ramach kompetencji Rady Sądownictwa Szkocji może ona powoływać także inne komitety. Każdy komitet musi w swoim składzie mieć co najmniej jednego członka Rady, ale w jego poczet mogą wchodzić także inne osoby, pod warunkiem że spełniają kryteria formalne, jakie są podstawą wyboru do Rady.

Obecnie, jak wynika z informacji zamieszczonej na stronie Rady, działają cztery takie komitety ${ }^{20}$, prowadząc sprawy znajdujące się w polu zainteresowania Rady. Rada praktycznie działa zatem poprzez swoje komitety, które procedują permanentnie, podczas gdy posiedzenia Rady odbywają się dwa razy do roku.

Rada Sądownictwa Szkocji jest zatem ciałem doradczym i opiniodawczym, powołanym z inicjatywy Przewodniczącego Sądu Najwyższego; jej zadaniem jest przede wszystkim konsultowanie i wyrażanie woli w sprawach związanych z funkcjonowaniem wymiaru sprawiedliwości i systemu sądownictwa. Jest to jednak ciało o charakterze wewnętrznym, nie ma zatem pozycji ustrojowej, która zapewniałaby Radzie pełnienie funkcji w systemie władz publicznych. Tak zatem Rada zazwyczaj nie zajmuje stanowiska w swoim imieniu ani nie komentuje wydarzeń publicznych, choć wiosną 2017 roku sformułowała swoje stanowisko wobec niezawisłości sędziowskiej w Polsce, w ślad za podobnym stanowiskiem zajętym przez Radę Sądownictwa Anglii oraz Europejską Sieć Rad Sądownictwa ${ }^{21}$.

\section{RADA NOMINACJI SĘDZIOWSKICH}

Jednak oprócz Rady Sądownictwa w Szkocji funkcjonuje jeszcze inne ciało kolegialne — Rada Nominacji Sędziowskich (The Judicial Appointments Board for

19 „On such other occasions as, having taken the advice of the Executive Committee, the Lord President considers appropriate"- pkt 9 Statutu.

20 The Welfare and Support Committee, the External Relations Committee, the Conduct Committee i the Information and Communications Technology Committee. http://www.scotland-judiciary.org.uk/Upload/Documents/MembersoftheJudicialCouncilanditscommitteesNovember2015. pdf (dostęp: 3.10.2018).

21 Stanowisko Rady Sądownictwa Szkocji mozna znaleźć na stronie: http://www.scotland-judiciary.org.uk/24/1783/Statement-of-the-Judicial-Council-for-Scotland-on-judicial-independence-in-Poland (dostęp: 3.10.2018). 
Scotland - JAB). Powołanie Rady poprzedzone było rosnącym niezadowoleniem z powodu obserwowanego wpływu czynników politycznych, szczególnie rządowych, w procesie powoływania sędziów ${ }^{22}$, a także zarzutami nietransparentności procesu ich powoływania ${ }^{23}$. Rada powstała w 2002 roku, choć początkowo nie miała podstaw ustawowych, co zresztą było powodem licznych zarzutów — zarówno wobec niej, jak i rządu, który ją powołał. W 2006 roku rząd szkocki przedstawił rekomendację dotyczącą zwiększenia gwarancji rzetelnego i efektywnego procesu sądowego ${ }^{24}$, w tym przede wszystkim gwarancji niezawisłości sędziowskiej w Szkocji (Strengthening Judicial Independence in a Modern Scotland), proponując między innymi stworzenie ustawowych podstaw funkcjonowania Rady jako ciała odpowiedzialnego za przedstawianie kandydatur na stanowiska sędziowskie. Tak też się stało - Judiciary and Courts (Scotland) Act z 2008 roku ustanowił Radę organem odpowiedzialnym za przedstawianie nominacji sędziowskich. Rada ma status pozaministerialnego podmiotu prawa publicznego (non-departmental public body).

Od 2002 roku Rada składała się z członków wywodzących się ze środowisk zarówno prawniczych, jak i nieprofesjonalnych. Wchodziło do niej pięciu członków niereprezentujących zawodów prawniczych, a także trzech reprezentantów środowiska sędziowskiego oraz dwóch przedstawicieli innych zawodów prawniczych (adwokatów i solicitorów), przewodniczącym Rady zaś była osoba spoza środowiska zawodowych prawników. Obecnie, to jest pod rządami ustawy o władzy sądowniczej i sądach ${ }^{25}$, Rada Nominacji Sędziowskich składa się z dwunastu osób. Czterech członków to sędziowie, wyznaczeni przez Przewodniczącego Sądu Najwyższego, przy czym dwóch z nich musi pochodzić z Sądu Najwyższego (Court of Session), choć nie mogą to być ani Przewodniczący (Lord President), ani Lord Justice Clerk. Spośród dwóch pozostałych członków wywodzących się ze stanu sędziowskiego jeden musi być wyznaczony spośród szeryfów głównych, drugi zaś spośród szeryfów. Dwaj kolejni członkowie Rady Sądownictwa pochodzą spośród osób wykonujących zawody prawnicze (musi to być jeden adwokat i jeden solicitor). Aż sześciu członków Rady to osoby pochodzące spoza środowiska prawniczego; członkowie ci są powoływani w skład Rady przez szkocki rząd (Scottish Ministers), podobnie jak reprezentanci szeryfów i głównych szeryfów, a zatem większość składu Rady powoływana jest przez szkocki rząd ${ }^{26}$.

Radzie Nominacji Sędziowskich przewodniczy osoba wybrana spośród członków, którzy nie są prawnikami. Przewodniczącego powołuje Rada Ministrów. Ka-

22 W 2000 roku w sprawie Starrs v. Ruxton uznał, że powoływanie szeryfów przez szkocką egzekutywę na roczne kadencje z możliwością ponownego wyboru nie daje gwarancji niezawisłości sędziowskiej i proces przed tak ukształtowanym organem sądowym nie spełnia kryteriów rzetelnego procesu.

23 G.F.M. Little, op. cit., s. 188-189.

24 Ibidem, s. 190.

25 Sekcje 9-18 Judiciary and Courts Act 2008.

26 Sec. $1 \S 2$ i 3 tego aktu; zob. G.F.M. Little, op. cit., s. 198. 
dencja przewodniczącego trwa cztery lata, jednak może on zostać ponownie powołany. Sposób ukształtowania i organizacji Rady, a w szczególności znaczny udział osób niewykonujących zawodu sędziego ani innych zawodów prawniczych stał się i pozostaje przedmiotem wielu kontrowersji; przeciwnicy tego rodzaju struktury JAB podnoszą, że nieprofesjonalny skład i przewodniczenie Radzie przez osobę spoza stanu sędziowskiego odbiega od przyjętego w państwach europejskich modelu samorządności władzy sędziowskiej i zapewnienia stanowi sędziowskiemu wpływu na nominacje ${ }^{27}$. Inna kategoria zarzutów dotyczy dość nieostrych zdaniem oponentów kryteriów, jakie Rada Nominacji Sędziowskich stosuje, dokonując rekomendacji kandydatów; są to kryteria „zasług” (merit), którym towarzyszą od pewnego czasu wytyczne dotyczące potrzeby różnorodnego ukształtowania stanu sędziowskiego, tak aby jego struktura odpowiadała różnorodnej strukturze społeczeństwa szkockiego ${ }^{28}$.

Zadaniem Rady jest przedstawianie rekomendacji osób na stanowiska sędziów, w szczególności na stanowiska: senatorów Kolegium Sprawiedliwości (Senator of the College of Justice), przewodniczącego Sądu Ziemskiego (Scottish Land Court), szeryfów głównych (Sheriff Principal), szeryfów niezawodowych (Part-time Sheriff, Summary Sheriff), a także sędziów, którzy pełnią kadencyjne funkcje w Trybunale Sprawiedliwości UE, Europejskim Trybunale Praw Człowieka, oraz przewodniczących szkockich trybunałów.

Rekomendacje te przedstawiane są premierowi. Następnie procedura przybiera dwojaką postać - co do zawodowych stanowisk sędziowskich premier zobowiązany jest skonsultować kandydatów z Przewodniczącym Sądu Najwyższego, a następnie przedstawić monarsze $\mathrm{z}$ wnioskiem o powołanie konkretnej osoby na to stanowisko. Co do pozostałych urzędów sędziowskich (Temporary Sheriff Principal, Part-time Sheriff oraz Part-time Summary Sheriff), nominacji dokonuje rząd szkocki ${ }^{29}$.

\section{INNE CIAŁA OPINIODAWCZE - SZKOCKA RADA WYMIARU SPRAWIEDLIWOŚCI W SPRAWACH CYWILNYCH}

Struktura sądownictwa Szkocji jest dość złożona i oparta na wielowiekowej tradycji, a różnorodność urzędów sędziowskich i funkcji zajmowanych w sprawowaniu wymiaru sprawiedliwości lub w związku z jego sprawowaniem jest imponująca. Także liczba ciał i rad opiniodawczych i doradczych w różnych sferach wymiaru sprawiedliwości nie jest mała - wyżej przedstawiono dwie, które pełnią funkcje

27 Ibidem.

28 Ibidem, s. 197.

29 Za: https://www.judicialappointments.scot/about/values-objectives-and-aims (dostęp: 4.10.2018). 
kojarzone z radami sądownictwa jako organami odpowiedzialnymi za czuwanie nad niezależnością sądów lub odgrywające rolę wyraziciela interesów stanu sędziowskiego. Oprócz przedstawionych w szkockim wymiarze sprawiedliwości nie brakuje jednak także innych ciał o podobnym charakterze; jak już wspomniano funkcjonują stowarzyszenia sędziów należących do poszczególnych grup, w tym Rada Sędziów Sądu Najwyższego (Judges' Council Court of Session), stowarzyszenie sędziów okręgowych (szeryfów — Sheriffs' Association) czy niepełnoetatowych szeryfów (Part-time Sheriffs' Association) oraz stowarzyszenie sędziów pokoju (Scottish Justices Association).

Ale oprócz tego w Szkocji powoływane są także inne rady i ciała opiniodawcze związane z funkcjonowaniem wymiaru sprawiedliwości, jedną z nich jest Szkocka Rada Wymiaru Sprawiedliwości w Sprawach Cywilnych, powołana 28 maja 2013 roku na podstawie ustawy o Radzie Wymiaru Sprawiedliwości w Sprawach Cywilnych i pomocy prawnej w sprawach karnych (Scottish Civil Justice Council and Criminal Legal Assistance Act 2013). Rada ta zastąpiła dotychczas funkcjonujące Rady Sądu Najwyższego oraz Szeryfów (Court of Session Rules Council, Sheriff Court Rules Council) i przejęła ich dotychczasowe kompetencje. Rada przygotowuje projekty zmian w prawie cywilnym, a także doradza Przewodniczącemu Sądu Najwyższego w sprawach związanych z rozwojem systemu wymiaru sprawiedliwości w sprawach cywilnych. Rada ta odpowiada także za stały przegląd sprawowania wymiaru sprawiedliwości w sprawach cywilnych, dokonując m.in. przeglądu orzecznictwa Sądu Najwyższego i sądów apelacyjnych oraz sądów szeryfów. Rada przygotowuje także i przedstawia Sądowi Najwyższemu projekt regulaminu sądów w sprawach cywilnych, a nadto projekt regulacji dotyczącej wysokości opłat sądowych oraz przygotowuje rekomendacje dotyczące zmian w systemie wymiaru sprawiedliwości w sprawach cywilnych w Szkocji ${ }^{30}$. Tego rodzaju rekomendacje przedstawiane są rządowi Szkocji oraz innych ciałom, w tym parlamentarnym, dlatego też uznać trzeba, że pozycja rady wykracza poza wewnątrzustrojowe kwestie sądownictwa.

\section{PODSUMOWANIE}

Przedstawiona regulacja oraz zaprezentowane instytucje działające w Szkocji w ramach sprawowania pieczy nad pozycją szkockiego wymiaru sprawiedliwości nie formują jednolitej struktury, tworząc wyraźnie zdywersyfikowany model partycypacji sędziów w ochronie niezależności wymiaru sprawiedliwości, powoływania sędziów, a także opracowaniu i przedkładaniu regulacji prawnych dotyczących sądownictwa. O ile Rada Sądownictwa Szkocji o czysto sędziowskim składzie jest organem wewnętrznym władzy sądowniczej, o tyle Rada Nominacji

30 http://www.scottishciviljusticecouncil.gov.uk/council (dostęp: 27.11.2019). 
Sędziowskich jest ciałem kolegialnym, ze znacznym udziałem osób spoza wymiaru sprawiedliwości, odpowiadającym za przedstawianie rekomendacji personalnego ukształtowania składu sądów. Pewien zadań i kompetencji wiązanych z ochroną niezawisłości sędziowskiej należy także do stowarzyszeń reprezentujących określone grupy hierarchii stanu sędziowskiego w Szkocji, a Szkocka Rada Wymiaru Sprawiedliwości w Sprawach Cywilnych przygotowuje projekty i propozycje regulacji dotyczących sprawowania wymiaru sprawiedliwości.

\title{
THE JUDICIAL COUNCIL FOR SCOTLAND AND THE JUDICIAL APPOINTMENTS BOARD FOR SCOTLAND
}

\author{
Summary
}

The article presents the structure, competences and functions of the two bodies responsible for protecting the independence of the judiciary in Scotland. The text also presents the reforms to which the Scottish judiciary has been subject in the 21 st century and the organisation of the judiciary in Scotland.

Keywords: Scottish judiciary, judicial appointments in Scotland, independence of the judiciary

\section{BIBLIOGRAFIA}

Delaney E.F., Judiciary Rising: Constitutional Change in the United Kingdom, „Northwestern University Law Review" 108, 2014, nr 2.

Field I., Crime Fighters and Border Guards: The Scottish Law Officers in Comparative Perspective, „Bond Law Review” 23, 2012, nr 2.

Harrison J., Judging the Judges: The New Scheme of Judicial Conduct and Discipline in Scotland, „Edinburgh Law Review” 13, 2009, nr 3.

Little G.F.M., The Reform of the Scottish Judiciary, [w:] Law-Making and the Scottish Parliament, red. E.E Sutherland, Edinbourgh 2014.

McCluskey J., Unnecessary and Misconceived: Some Reflections on the Judiciary and Courts (Scotland) Bill, „Edinburgh Law Review” 12, 2008, nr 2.

Pfander J E., Birk D.D., Article III and the Scottish Judiciary, „Harvard Law Review” 124, 2011, nr 7.

Sharp D., Parliamentary Sovereignty: A Scottish Perspective, „Cambridge Student Law Review” $6,2010$. 